\section{AN EXPERIMENT IN SOCIAL SCIENCE}

$\mathrm{T}$

HERE is a growing appreciation of the problem of the relation between management and labour : it is one which bristles with difficulties, in part because there is a lack of understanding on both sides and often, indeed, unwillingness to try to understand. As labour grows more and more independent, partly because of its political power, it becomes more necessary than ever to seek any and every means to promote such understanding, so that a factory can be run for the common weal, to give continuous remunerative employment to all connected with it, to give a fair return on the money invested in it, having regard to the risk, to set aside sufficient for depreciation and development so that the business may last for generations and not collapse exhausted in a few years like the wheat fields of the West after half a dozen crops.

If these prime essentials are agreed, then every worker, high or low, must actually earn, that is, produce goods of a value greater than his pay ; if he fail to do this, then he is a drag on the concern and must be removed or it will fail. The usual stupid remedy for bad times is to reduce wages; a more scientific solution would be to increase the amount of work and cheapen the product, thereby making it more competitive and easier to sell. Unfortunately, the economics of bad and good times are more complex than the above simple basic principles, but none the less they are still largely applicable in most factories.

It is the task of management to see that every worker is able to earn more than his pay by adequate production, also that quality is maintained, research and development fostered, plant and machinery kept in order. Over and above this, good management has an even more important task based on the recognition that the workers are not herds but individuals with hopes and aspirations, people to lead rather than drive. In the old family concern the boss-"old Mr. Tom"-knew most of the workpeople by their given names and something about their hobbies; to-day this is much more difficult, especially when an overworked general manager has several thousands under him. Much can, however, be done, and it may be of interest to give an account of efforts made in a large factory employing both sexes some twenty-five years or more ago, largely before general interest was attracted to such ques. tions.

The work is conveniently grouped under the headings of education, recreation, health ; we anticipated Hitler in devoting most of the efforts to the young people, remembering both that they are most impressionable and are continuously growing up.

Education. All young persons, as the Factory Act calls them, had to pass a certain standard before being taken on. The girls had to pass the top standard to qualify for the 'cleaner' work, for which there was allways a long waiting list. The top standard was also required for the laboratory, to which a limited number were recruited each year after an interview by the chief chemist. The laboratory was regarded as the training ground for the staff. Everyone in it had to go to evening classes at the expense of the firm, at first in the home town and afterwards at the nearby city, to which travelling expenses were paid : some obtained external B.Sc. degrees in this way. (This was before the days of occasional day-time release which Dr. A. P. M. Fleming has since sponsored.)

At the end of the year the progress of each man was reviewed and a few 'square pegs' discharged. It was considered fairer to do this at the start than let them grow old in jobs for which they had little aptitude and probably less inclination. Such a system gives a larger number of recruits the chance of making good. Payment was by an age scale. The laboratory lads were encouraged in every way to take part and help in the social work and to develop any talent for organization or leadership. One got to know them well and to select those best fitted to be under-managers, alternatively research assistants. To-day some of them are managers in responsible positions.

On a smaller scale, the same progressive training was extended to the technical director's personal staff, which handled all works questions not pertaining to the actual processes. It was ripe for extension to the whole works, where any promising boy, generally discovered through the Scouts, was picked out and given a chance.

The advantage to the lads of this training is obvious : what the firm gained was a reservoir of men of all grades of ability available to fill gaps at home or abroad. We knew them and they knew our methods, a system which was infinitely more satisfactory than bringing in strangers.

Recreation. It is essential that the workers should manage their own affairs, but they need and welcome guidance in their organization. They do not want recreation arranged for them by a welfare staff. Our Girl Guides were highly successful, there was a waiting list to join them and a high standard of conduct was set; here more than anywhere was there an opportunity of teaching the team spirit. The Boy Scouts were also popular, but the boy at this age very properly is more inclined to go his own way.

The company had provided a particularly fine recreation hall and canteen, including a theatre, which was the centre of a variety of activities all managed by the work-people and staff. The most interesting were the dances, sectional or large, which were self-supporting. These were visited by the technical director and certain members of the staff and their ladies-there was no formality or segregation. We were told our presence was desired and helped to make the affairs a success. I have no more pleasant recollection than the comparison of the dresses and general appearance of the girls at the beginning of these efforts and fifteen years later, and the young men had equally progressed. This social progress was in itself ample payment for much time devoted to this work - the girls made better marriages as one consequence of it. The credit was due in particular to the tact and general self-sacrifice of our lady manager, but it was personal also to a surprising extent, for on a change of management which withdrew the personal touch, the social functions languished and became less successful.

Interdepartmental games are a good method of fostering pride in the departments, and competitions for shields and cups, which are exhibited in the workshop all the year, do a lot of good in making workers feel they are part of a large family and not mere hands. The success of these, however, depends on a display of interest in them by the management; they tend to die away if left to the players themselves. 
We never found a means of really breaking down the barrier between works and office on the social side-a stupid distinction which in reality was nonexistent-for the many offices in the works counted as works staff and played with us. Perhaps we did not try hard enough and left the office folk to find out what they were missing.

Health. The health of the worker should be a matter of concern to management. Quite apart from occupational diseases and epidemics, undue sickness in any one department is a sign that something is wrong and needs investigation. Departmental as well as general statistics should be reported. An undue amount of sickness among the girls led to the discovery that in order to get to work in time in the morning, many of them neglected to have a proper breakfast. A 40-minute-later start, that is, a 44- instead of a 48-hour week, was tried as an experiment, with an agreement on the part of the workers that they would try to maintain output and on ours that they would not lose pay. When things had settled down, it transpired that in the long run a slightly larger output was obtained and the sickness figure fell considerably. A watch on the sickness figure of small sections usually led to the discovery and rectification of the cause.

Many sections of the firm were working under conditions of limited floor space while new buildings were under way. Increased demand could not therefore be met by putting on extra girls, but only by higher production from the pieceworkers. To this end we made what are now called motion studies, an operation requiring the greatest tact. Varying rest periods, change of work so as to bring another set of muscles into play, height of seat and accessibility of components were all studied, with the result that we were satisfied that we did obtain the highest output per girl (paid for as piecework) that could be kept up day by day for a number of weeks. On one occasion the opportunity presented itself of working in circumstances in which the same girls, at their own wish, did even more, working for three days only per week. They kept this up for two weeks and then asked to give it up; the strain was too great and they found themselves tired for the rest of the week.

Overtime should be sparingly used for young persons; older men like it to provide a bonus for holiday occasions, but in the long run the same amount of work was done as if only normal hours had been worked.

Motion study under a special officer is to-day a regular practice, and much can be done to make the work easier. On the whole, operatives like monotony, something they can do with their fingers mechanically while they chatter and sing. They are suspicious of change unless they feel they have absolute confidence in the fair dealing of the management, and in particular a right of personal appeal to the top.

One of the most difficult things is to get hold of ideas from the workers to improve the process. There is the fear that the foreman will annex it as his own, or that if one goes past him that he will take it out of the individual. Suggestions boxes too often contain claims regarding alterations which the engineers already have in hand. The more management at the top knows the work-people, the easier it is to get a hint here and there where the shoe pinches, and to take equally quiet methods to put the trouble right.

Our wages were a few shillings above the local average, so that living on the same seale our people were just that amount better off. They were extraordinarily generous, as English working-people are, giving freely to help fellow-workers in adversity and to causes sponsored by us which commended them. selves. Perhaps I should say that all this was largely before the advent of the cinema, which has done so much to absorb the loose shillings from the people's pockets.

We were always seeking methods of giving extra benefits to the work-people, partly as a means of profit sharing, partly to shield them in adversity, and partly also with the hope of retaining our labour and not having constantly to take on new people. This aim was achieved, for our labour turnover was one of the lowest in Great Britain. We were early in the field in granting holidays with pay, depending only on good time-keeping. We gave a weekly wage bonus for length of service. We started pensions depending on the will of the board-non-contributory because any fund on an actuarial basis would have been too costly. We postponed co-partnership because of fluctuating profits-workmen do not like the years in which no dividend is paid.

Perhaps our greatest success was group life insurance-every man of long enough service was given a policy for a year according in amount to his standing and the report on his general proficiency. The minimum was $£ 100$, and many workers had twice this. The realization by the married man that if anything happened to him his wife and children would receive what seemed a large sum-enough to start a small shop and keep them from want-had a profound effect on his well-being. The cost was considerable, but I am sure we should have been amply repaid.

Perhaps what has been said is enough to portray a restless management always seeking to make work happier for all and to better the lot of the worker both at work and at home. A loyal band of helpers found zest in the cause while our reward was close at hand. Needless to say we had no strikes, a very minimum of friction in spite of the fact that externally the years were very difficult ones, and a loyal response to any extra effort for which we asked.

The function of management vis-d-vis the worker is necessarily to drive, but when both sides under. stand each other, 'drive' becomes largely 'guide'.

\section{E. F. A.}

\section{PHYSICAL FEATURES OF COMET 194IC (DE KOCK)}

$\mathrm{R}$ H. STOY has described (Mon. Not. Roy. Astro. Soc., 101, 7 ; 1941) the chief physical features from an examination of 24 plates taken with the Cape astrographic refractor on 18 days between January 20 and March 6 . The plates were projected on to a piece of paper with the aid of an enlarging lens and a 500-watt lantern, the main features of the comet being then sketched in. The orientation of the drawing and position angles were derived from the lines, the positions of which were known, and when these had been completed an attempt was made to match the outlines of the observed caps by known curves.

It is interesting to notice that in nearly every case it was possible to find a catenary that fitted satisfactorily. There was a remarkable similarity between 